\title{
Work-family conflict: An investigation on job involvement, role ambiguity and job demand: Moderated by social support
}

\author{
Sobanah Dhevi Tharmalingam ${ }^{1}$, Muhammad Awais Bhatti ${ }^{1,2}$ \\ ${ }^{1}$ Othman Yeop Abdullah Graduate School of Business, University Utara Malaysia, Sintok, Malaysia \\ ${ }^{2}$ School of Business Management, College of Business, University, Utara Malaysia, Sintok, Malaysia
}

\section{Email address:}

shoba_gal@yahoo.com (S. D. Tharmalingam), awais@uum.edu.my (Muhammad A. Bhatti)

\section{To cite this article:}

Sobanah Dhevi Tharmalingam, Muhammad Awais Bhatti. Work-Family Conflict: An Investigation on Job Involvement, Role Ambiguity and Job Demand: Moderated by Social Support. Journal of Human Resource Management. Vol. 2, No. 3, 2014, pp. 52-62.

doi: $10.11648 /$ j.jhrm.20140203.12

\begin{abstract}
There are many predictors that determine the work-family conflict among employees and one of the significant predictor is related to the organization. There exist fewer studies that focus on influence of job involvement, role ambiguity, job demand and social support towards the work-family conflict. The present study fill in the gap by investigating the relationship between job involvement, role ambiguity, job demand, social support and work-family conflict among the administrative staff in University Utara Malaysia (UUM), Kedah, Malaysia. Two hundred (200) questionnaires were administered to administrative staff in the University. The regression analysis was used to analyze the data and the results show that Work-Family Conflict is negative and significantly influence Job involvement and Social Support, while positively related with Job demand. However, moderating effect of social support was found to be significant among Job involvement, Role ambiguity and Job demand. The practical implications of the finding include the basic understanding of the causal factors which influence administration staff's with work-family conflict to leave has important practical insinuation for the management and the university administration and among others also. Moreover, this research can help the people to prepare themselves with appropriate manageable conflict ways.
\end{abstract}

Keywords: Work-Family Conflict, Job Involvement, Role Ambiguity, Job Demand, Social Support, Malaysian University

\section{Introduction}

Nowadays, Work-Family Conflict appears in the life of most people without their knowledge. Work-Family Conflict which takes place in human's daily life generates problem in their work performance where in this era of globalization most of people engaged in conflict. This may affect the employees, which make them unable to concentrate on their work or family activities. Work-Family Conflict has been described as two way relationship between work interference family and family interface work task (Frone, Russell \& Cooper, 1992) [35]. Moreover, the work-family conflict occurs because conflict appears between work roles and family roles (Beutell, 2013) [12]. Previous researches have shown that there are increased in the turnover intention, parental discussion, lower the job satisfaction, trim down the organizational commitment and the family satisfaction transmit work-family conflict (Karatepe \& Kilie, 2007; Hellman, 1997;Koys, 2001; Simon, Kummrling \& Hasselhorn, 2004) [46] [41] [50] [74].

According to O'Driscoll \& Colleagues (2004) [63], coworkers have moderated the relationship of the workfamily conflict and satisfaction. Besides that, there is strong support that similar research has been conducted to determine the work-family conflict using perceived coworkers support as the moderator and estimated that work-family conflict is significantly related to job satisfaction (Ng \& Sorensen, 2008) [62]. Partners also play an important role in contributing towards the Work-Family 
Conflict. The interaction of work life and family life might also lead to work-family conflict among women and men (Canivet et al., 2010) [23]. The largest part of single mothers whom cross the threshold the working area are stated as holding the highest percentage to be involved in the work-family conflict (Jackson, Tal \& Sullivan, 2003) [43]. There is statistical evidence that the divorced among Muslim is about 210,326 people and 41,507 non-Muslim in Malaysia is mostly estimated to be influenced by work and family problem (Poobalan, 2013) [66]. In order to reduce the negative effect which appears from the Work-Family Conflict, employees at all management levels need to manage the sources of conflict consistently towards their family roles and work roles.

The reason to conduct this study is to inform the people regarding the way to solve the conflict which appear among the administrative staff in Malaysian university. The appearance of the work-family conflict among the employees is considered as the major problem to conduct this study. This study can be said as different from other paper since the Social support has been used as the interest predictor to investigate the strengtheners of relationship within the independent variables and the dependent variable.

\section{Literature Review}

The purpose of this section is to review previous work related to the present study as well as related theories in order to validate the research theoretical framework employed in this paper. The section started by reviewing literature on work-family conflict known as the dependent variable, followed by the independent variable which is job involvement, role ambiguity and job demand as well as social support as a moderator.

\subsection{Work-Family Conflict}

Work-family conflict is normally stated as two ways of study regarding the category of conflict which can be identified as the work to family conflict and family to work conflict (Zhang, Griffeth \& Fried, 2012)[81]. Besides that, work-family conflict delay family performance since they need to manage the work compulsion which obstruct the capability to provide the sufficient management among the child care (Zhang et, al. 2012) [81]. Boles, Howard \& Donofrio (2001) [14] stated that work-family conflict is reflecting the individual ability to perform their works with a lot of demand carried out by them towards their work performance and their home or family activity. According to Greenhaus \& Powell (2006)[37], the work-family conflict will affect the work and family roles in terms of high expectation towards demand in every role besides lower down the performance level of the employees.

There are various types of conflict which might impact on work-family conflict and in this study there are mainly three categories of conflict been used to conduct this study. According to Greenhaus \& Beutell (1985) [38] time, strain and behavior related to the work-family conflict. Moreover, the behavior conflict also will give impact towards the work-family conflict if the person does not work effectively and does not play their role appropriately within the work and family role which will create low effectiveness (Greenhaus \& Powell, 2006)[37]. There have been some research findings, which argue that the ending of work involved or job involvement include the work role conflict, work role overload and work-role ambiguity, all these variables considers as affecting the work-family conflict (Razak, et. al., 2011) [68].

\subsection{Job Involvement}

Job involvement has been described by Kanungo (1982) [45]"psychological identification with a job"(p.97). Similarly, according to Ahmad (2008) [3] the involvement of high percentage of women towards the job area is increasing the study within the family and work roles. There are increases in job involvement, which may create the job look after their own part of working environment should have conceited on their work (Chang, 2002) [26]. Furthermore, role overload and role conflict or factor of work-involvement and authority of the work-family conflict related to the work-family conflict (Carlson \& Kacmar, 2000; Razak et, al., 2011) [25] [68].

As suggested by Greenhaus and Beutell (1985) [38], if people are involved with high level of involvement in executing their role or work, it may raise up their inter-role conflict which is work-family conflict in both work role and family role. As stated by Frone, Russell \& Cooper (1992) [36], other factors such as the family stress, job stress and family involvement, which relate to job involvement might contribute to the work-family conflict. "The relationship or role family involvement plays in workfamily conflict, family involvement must be more inclusive allowing for both the number and salience of various constraints to be considered" (Boyar et al., 2003) [15].

There are several studies that show a negative relationship between the job involvement and the workfamily conflict. Razak, Yunus \& Nasurdin (2011)[68] stated about work overload and job involvement towards the work-family conflict. This study involved 391 full time local doctors in 9 public hospitals in Peninsular Malaysia and found a negative relationship between job involvement and work-family conflict. Lawrence (2013) [53] investigated the work involvement and family involvement towards work-family conflict was found to be not significant and negatively related.

H1: Job Involvement negatively related to Work-Family Conflict.

\subsection{Role Ambiguity}

The degree of individual insecurity in their job anticipation is called role ambiguity (Baral \& Bhargava, 2010; Epie, 2009; Fayankinnu \& Alo, 2007; Akanji, 2012) [8] [31] [34] [4]. Role ambiguity has been described by 
Kahn, Wolfe, Quinn, Snock \& Rosenthal (1964) [48] as "the single or multiple roles that confront the role incumbent, which may not be clearly articulated in terms of behaviors or performance levels". This statement is supported by (Spector, 1997, p.39; Bolat, Bolat \& Yuksel, 2011; House and Rizzo, 1972) [76] [13] [42], where they describe role ambiguity as a condition of doubtless when conducting the work of employees. Besides that, the first type of role ambiguity occurs when there are low salient and the information based on the work are less known to be adopted by the individual in their role (Beard, 1996)[18]. The second type of role ambiguity is that employees mostly cannot predict or evaluate their responsibilities (Doherty \& Hoye, 2011; Sakires, Doherty \&Misener, 2009) [29] [71]. Moreover, the role ambiguity effect a person by creating disappointment within their role, nervousness, worry, concern, deform reality and execute less effectively (Rizzo, House \& Lirtzman, 1970, p. 151) [69].

There exist numerous studies that show the existence of a positive relationship between the role ambiguity and the work-family conflict. Chin, Ismail, Ahmad \& Kuek (2012) [27], conducted research on the impact of job stress on workforce, which showed that there is a significant and positive relationship between role ambiguity and workfamily conflict. Specifically, Thiagarajan, Chakrabarty, Lueg \& Taylor (2007) [78] conducted study on work, family role strain among 381 respondents from the marketing research firm in the US, Alaska and Hawaii. The result shows that there is significant and positive relationship between the role ambiguity and work-family conflict. There are also several studies that have shown the existence of a negative relationship between the role ambiguity and the work-family conflict. Beige, Ershadi \& Shirmohammadi (2012) [11], conducted a study on workfamily conflict among Iranian operating room personnel. Besides that, Carlson, Kacmar \& William (2000) [24], study work-family in organization and found a nonsignificant and negative relationship between role ambiguity and work-family conflict.

H2: Role Ambiguity positively related to Work-Family Conflict.

\subsection{Job Demand}

Mauno, Kinnunen \& Ruokolainen (2006) [58] mentioned that, "physical, psychological, social or organizational features of the job, requiring physical or psychological effort and energy from an employee and are consequently related to psychological and psychological costs (i.e., strain)" (p. 212). Most of employees related to job demands are unable to handle the conflict from their work or family role, this creates an emotional exhaustion (Karatepe, 2013) [47]. Burke \& Greenglass (2001) [16] concluded that there are strong relationship among the work demands and job stresses towards work-family conflict. By working for a long period of time the employees need to reduce their family time, which they allocated to spend with their family and by this they can easily involve themselves in the work- family conflict (Yildirim \& Aycan, 2008)[81].

There are some previous studies which show a positive relationship between job demand and work-family conflict. Beham, Drobnic \& Prag (2011) [10] also conducted study on the job demand and work-family conflict among 199 employees in German from the IT, retail and healthcare industry. They found that job demand is significantly and positively related to work-family conflict. Recently Bakker, Brummelhuis, Prins \& Heijden (2011) [7] conducted studies and found that there is a significant and positive relationship between job demand and work-family conflict. H3: Job Demand is positively related to Work-Family Conflict.

\subsection{Social Support}

The theoretical viewpoint based on social support research point out that the availability of the social support, donates to comfort (Lakey\& Cohen, 2000) [52]. The social support is divided into the supervisor support, coworkers support, organizational support and family support. As suggested by Hammer, Kossek, Yragui, Bodner and Hanson (2009) [40], meaning of supervisor support which include in the work-family conflict where at this stage they used to care about the individual work-family and they involve in helping behavior to manage or solve the problem that occur in the work-family conflict. There are findings which stated that social support are involved with the strain conflict where it's give a strong impact towards the life domain and the influence of the strain, conflict towards the work-family conflict (Westman \&Etzion, 2005) [80].

According to Allen (2001) [5], work-family conflict will be influenced by social support, but emphasize about the job demands which occur from the stress factor besides helps to influence on the work and family performance. Social support used to be viewed in the social source where they have found the influence on the work-family conflict (Adam et. al., 1996; Erdwins, Buffardi, Casper \& O'Brien, 2001)[2][32]. There is a lack of studies which comprises a social support as the moderator which will affect work support and work-family conflict (Dormann \& Zapf, 1999) [30]. It has been identified that there is a negative relationship between the social support and work-family conflict. In particular, Thomas and Ganster (1995) [79], shows the significant indirect and the negative effect towards the social support on work-family conflict. Neilson, Calson \& Lankau (2001) [60], suggested a negative and non-significant relation among the social support and workfamily conflict.

H4: Social Support negatively related to Work-Family Conflict.

H5: Social Support moderates the relationship between Job Involvement and Work-Family Conflict.

H6: Social Support moderates the relationship between Role Ambiguity and Work-Family Conflict.

H7: Social Support moderates the relationship between Job Demand and Work-Family Conflict. 


\section{Framework}

The following research framework shows the conception of the research that describes the relationship among the independent variables, moderating variable and dependent variable. Thus, the research framework for this study as depicted in Figure 1 shows the relationship between the independent variables (Job Involvement, Role Ambiguity and Job Demand) and a moderator which is Social Support and the dependent variable is Work-Family Conflict.

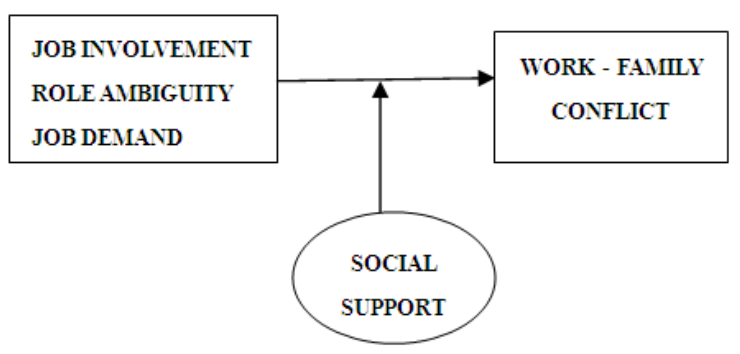

Figure 1. Research Framework

\section{Methodology}

The purpose of this study is to investigate the relationship between the job involvement, role ambiguity, job demand, social support and work-family conflict among Malaysian academic staff. The study adopts cross-sectional research design. The unit of analysis is the administrative staff in the public university (University Utara Malaysia) located in Sintok, Kedah. The respondents (administrative staff) are 1,961 people for this study. According to Krejcie and Morgan's (1970) [51], to resolve the required sample size for the present study, sample size willpower procedure is used.

Hence, following Krejcie \& Morgan's (1970) [51] the sample size determination procedure, a sample size of 322 would be required for a population of 1,961 people. However, the convenience sampling technique was used because the sample frame does not exist which is nonprobability sampling technique have been used in conducting this research. Overall, 400 questionnaires were distributed among all the administrative staff in UUM and 200 questionnaires were return from the respondents and used in conducting this research.

\section{Measurement of Variables}

In this part, all the variables in this study are measured according to the past study items which have been developed by the prior researchers in their study. The 5 point Likert scale was used to collect the data, where 1 indicates Strongly Disagree to 5 which is Strongly Agree adopted from Rahim et al. (2012) [67]:

- Work-Family Conflict was measured using five items (e.g., "The demands of my work interfere with home, family and social life") developed by Boles, Howard and Donofrio, (2001); Netermeyer, Boles \& Mc
Murrian, (1996) [14] [61].

- To assess job involvement there are five items (e.g., "The major satisfaction in my life comes from my work") adopted from Lodahl \& Kejner (1965) [54].

- In order to measure the role ambiguity construct, four items (e.g., "There are clear, planned goals and objectives for my job") were adapted for the measurement made by Rizzo, House \& Lirtzman (1970) [69].

- In the present study, the Job demand was assessed using four items (e.g., "My job requires all of my attention") developed by Boyar, Carr, Mosley \&Carson (2007) [20].

- In order to measure the social support construct, 16 items (e.g., "My supervisor goes of his/her way to make my life easier") were adapted from the measurement adopted by Parasuraman \& Greenhaus (1992) [65].

\section{Findings}

This research uses the Statistical Package for Social Science (SPSS) Version 19 to analyze the data collected from the respondents. The collected data was analyzed using SPPS to find out the frequency distribution, descriptive statistics, correlation analysis, reliability test and regression analysis. Frequency distributions were generated from the respondent personal data (classification variable). The Cronbach's alpha was also calculated from the collected data and computed variables in the average inter correlations within the items which measured each of the concepts.

The hypothesis testing was analyzed by the Regression analysis with the acceptable Cronbach Alpha values of 0.60 . Basically, Regression analysis makes the researchers easily understand about the value of the dependent variable changes when any one of the independent variable is fluctuate but the other independent variable is used to be fixed. Multiple regression analysis was used to identify the moderating effect of social support towards the dependent variable and independent variables. The minimum acceptable value for Cronbach Alpha is 0.60 reported by Robinson, Shaver \& Wrightsman (1991) [70].

Table 1. Reliability Statistics of the Study Variables

\begin{tabular}{lll}
\hline Variable & No. of Items & Cronbach Alpha \\
\hline Work-Family Conflict & 5 & .90 \\
Job Involvement & 5 & .75 \\
Role Ambiguity & 4 & .81 \\
Job Demand & 4 & .68 \\
Social Support & 16 & .91 \\
\hline
\end{tabular}

\subsection{Table 1. Reliability Statistics}

The demographic profile shows that there are 80 male respondents (40\%) and 120 female respondents out of 200 respondents. One hundred and one (101) respondents $(50.5 \%)$ with less than 31 years and there are 67 
respondents $(33.5 \%)$ with $31-40$ years. Furthermore, there are 27 respondents $(13.5 \%)$ in between $41-50$ years and only 5 respondents $(2.5 \%)$ that are from $51-60$ years old. Furthermore, there are 74 respondents $(37 \%)$ who are single, 124 respondents are married respondents $(62 \%)$ and there are 2 respondents (1\%) from others marital status. Moreover, the large number of respondents is Malay people which show 193 respondents representing (96.5\%), there are 4 Indian respondents (2\%), just 1 Chinese respondent $(0.5 \%)$ and the others races contributed from 2 respondents (1\%). Similarly, there are 195 respondents $(97.5 \%)$ that are Muslim, Hindu respondents are around 4 representing 2\% and just 1 Buddhist respondent (0.5\%). On the other hand, the education level of the respondents whom have obtained their degree are 128 respondents (64\%), holding masters or $\mathrm{PhD}$ are 43 respondents $(21.5 \%)$ and just 29 respondents $(14.5 \%)$ is from Spm, Stpm and Diploma level. There are 100 respondents $(50 \%)$ who have gained $1-5$ years working experience, 47 people (23.5\%) from 6-10 years working experience and 25 respondents $(12.5 \%)$ have gained $11-15$ years working experience. Next are 16 respondents $(8 \%)$ have gained 16-20 years of working experience, 11 respondents (5.5\%) from 21-25 years' experience and there is just one person (0.5\%) from 26-30 years working experience.

The correlation results which consider the level of significant correlation among the study's variables are represented in Table 2 below. As noted in the table below, job involvement was strongly significantly and negatively related to work-family conflict $(\mathrm{r}=-0.38, \mathrm{p}<.05)$, role ambiguity also illustrated that it is positively and significantly related to job involvement $(\mathrm{r}=0.19, \mathrm{p}<0.1)$. Accordingly, job demand is negatively related and shows the significant relationship with role ambiguity $(\mathrm{r}=-.25$, $\mathrm{p}<$. 01). Furthermore, the social support shows the significant and positive relationship among three variables. First of all, social support significantly influence the workfamily conflict $(\mathrm{r}=.15, \mathrm{p}<.05)$ and followed with the influence towards job involvement by social support shows the significant and negative relationship $(\mathrm{r}=-.67, \mathrm{p}<.01)$. Finally, social support also display that there is a significant relationship towards the role ambiguity and shows a negative relationship $(\mathrm{r}=-.24, \mathrm{p}<.01)$. For the hypothesis consideration the regression analysis used to estimate whether the hypothesis is acceptable or not acceptable for this study. On the other hand, the mean and standard deviation for the five point scale which represent the variables in this study (Job Involvement, Role Ambiguity, Job Demand, Social Support and Work-Family Conflict), ranged from 2.39 to 3.63 , and 0.53 to 0.77 for mean and standard deviation respectively.

Table 2. Means, Standard Deviations and Correlations for Study Variables

\begin{tabular}{|c|c|c|c|c|c|c|c|}
\hline Variables & Mean & SD & 1 & 2 & 3 & 4 & 5 \\
\hline $\begin{array}{ll}1 & \text { Work family } \\
\text { Conflict }\end{array}$ & 3.30 & .77 & 1 & & & & \\
\hline Job Involvement & 2.57 & .61 & -.38 & 1 & & & \\
\hline Role Ambiguity & 2.39 & .60 & -.04 & .19 & 1 & & \\
\hline Job Demand & 3.30 & .57 & .06 & .07 & -.25 & 1 & \\
\hline Social Support & 3.63 & .53 & .15 & -.67 & -.24 & .02 & 1 \\
\hline
\end{tabular}

Note. ${ }^{*} \mathrm{p}<.05 * * \mathrm{P}<.01$ (one tailed test)

\subsection{Table 2. Means, Standard Deviation and Correlations}

The reason of multiple regression analysis is to resolve the aggregate effect of each independent variable (job involvement, role ambiguity and job demand), moderator (social support) and dependent variable (work-family conflict). From the findings of this study it is clear that the independent variables in the model explain $17.5 \%$ of the variance in work-family conflict. This shows the $\mathrm{R}^{2}$ value of 0.175 where it is supported by past researchers who states that even though the $\mathrm{R}^{2}$ value is around $1.5 \%(0.015)$ the result can be used in determining the relationship between variables (Falk \& Miller, 1992)[33].

The regression analysis results in Table 3 show how these four predictor variables (i.e., job involvement, role ambiguity, job demand, and social support) collectively influence work-family conflict. To test hypothesis 5, 6 and 7 which include the moderator, each variable among the independent variables were centered mean and this makes every variable to display zero mean. This minimizes collinearity within the product variable and element in components, hence this can be the best way to detect the interaction effect as a moderator (Tabachnick \& Fidell, 2011) [77].

Table 3. Result of the Multiple Regression Analysis

\begin{tabular}{|c|c|c|c|c|c|c|}
\hline Hypotheses & Variable & Beta & Std. Error & T-value & P-value & Findings \\
\hline $\mathrm{HI}$ & Job Involvement & -.67 & .11 & -5.95 & .00 & Supported \\
\hline $\mathrm{H} 2$ & Role Ambiguity & .05 & .09 & .58 & .28 & Not supported \\
\hline H3 & Job Demand & .15 & .09 & 1.60 & .06 & Supported \\
\hline H5 & Job Involvement x Social Support & -.37 & .01 & -2.53 & .01 & Supported \\
\hline H6 & Role Ambiguity x Social Support & .40 & .19 & 2.08 & .02 & Supported \\
\hline $\mathrm{H} 7$ & Job Demand x Social Support & .51 & .18 & 2.78 & .00 & Supported \\
\hline
\end{tabular}

Note: ${ }^{*} \mathrm{p}<0.10, * * \mathrm{p}<0.05, * * \mathrm{p}<0.01$. (One tailed test)

\subsection{Table 3.0 Result of Multiple Regression Analysis}

In particular, Hypothesis 1 have describe that job involvement variable is positively and significantly related to work-family conflict. As displayed in Table 3 above, negative and significant relationship were found between the job involvement and work-family conflict $(\beta=-.67 ; \mathrm{t}=$ - 
5.95; $\mathrm{p}<0.01)$ after conducting regression analysis. Thus, representing support for this hypothesis 1 .

Furthermore, Hypothesis 2 prospect that the role ambiguity positively influence work-family conflict. As shown in Table 3 the results point out that there are no significant relationship between role ambiguity and workfamily conflict $(\beta=.05 ; \mathrm{t}=.58, \mathrm{p}>.10)$. Hence, Hypothesis 2 was not supported, in the sense that the role ambiguity did not give any significant impact or did not contribute to work-family conflict.

Moreover, Hypothesis 3 proposed that job demand is positively related to work-family conflict. This hypothesis was also tested using the multiple regressions which as presented in Table 3. It shows the relationship among job demand and work-family conflict which is positive and significant relationship $(\beta=.15 ; \mathrm{t}=1.6, \mathrm{p}<.06)$. Consequently, the Hypothesis 3 is supported.

Hypothesis 4 stated that social support and work-family conflict is negatively related to work-family conflict. Examinations of results in table 3 represent that social support is significantly related and negatively influence work-family conflict $(\beta=-.29 ; \mathrm{t}=-2.23, \mathrm{p}<0.01)$. Thus, the hypothesis 4 was supported, shows that the higher the social support contribution to work-family conflict, the more it reduces the level of work-family conflict problem.

The first step, to find the product variable of the job involvement where the original value of computing variable, job involvement need to be subtracted from the mean such as $\left[\mathrm{C}_{-}\right.$job involvement $=$job involvement mean (2.57)]. The next step is need to take the product variable of the job involvement and times with product variable of social support [Job Involvement $\mathrm{x}$ Social support $=\mathrm{C}$ job involvement $\mathrm{x} C$ social support $]$ and the interaction term is derived here. The results show that significant and negative relationship of moderator among job involvement and work-family conflict $[\beta=-.37 ; \mathrm{t}=-2.53$; $\mathrm{p}<0.01]$.

These steps have been followed to describe hypothesis 5 and there have been similar steps used to determine the moderator relationship with the role ambiguity and job demand towards the work-family conflict to estimate hypothesis 6 and 7 to find out whether they are supported or not in this study.

Specifically, Hypothesis 5 mentions that the social support was moderator within the job involvement and work-family conflict. As seen in Table 3 above, shows negative and significant relationship has been identified between the social support towards job involvement and work-family conflict $(\beta=-0.37 ; \mathrm{t}=-2.53 ; \mathrm{p}<0.01)$. Thus, indicating support for this hypothesis 5 , the social support can be used as a moderator in the relationship between job involvement and work-family conflict because the support from others will reduce the work burden and reduce the work-family conflict.

Moreover, Hypothesis 6 said that the relationship between social support as a moderator among role ambiguity and work-family conflict. This has been identified as a positive relationship and significant which can use the social support as a moderator in estimating the relationship between role ambiguity and work-family conflict $(\beta=.40 ; \mathrm{t}=2.08 ; \mathrm{p}<0.05)$ as stated in Table 3 . Therefore, the result shows that the hypothesis 6 was supported. The information from the supervisor or coworkers can reduce the role ambiguity which appears among the employees and by this the work-family conflict can be decreased.

Lastly, Hypothesis 7 describes social support as a moderator between job demand and work-family conflict. As shown in Table 3 above, there is a significant and positive relationship between social support as moderator for job demand variable and work-family conflict variable $(\beta=.51 ; t=2.78 ; p<0.01)$. Hypothesis 7 shows that, the high influence of social support to the job demand can create lower work-family conflict to the employees.

\section{Discussion}

This section discusses the findings based on the dependent and independent variables through the objectives of the study. The first hypothesis forecast that job involvement is negatively related to work-family conflict. This hypothesis was strongly supported with the acuity of job involvement is significantly and negatively related to the work-family conflict. This finding has been proven by the support of the past studies where it has been stated that there is a significant and negative relationship between job involvement and work-family conflict (Razak et al., 2011; Luk \& Shaffer, 2002; Lawrence, 2013; Narayanan \&Savarimuthu, 2013) [68] [55] [53] [59]. This result shows the negative relationship between job involvement and work-family conflict among the administrative staff in University Utara Malaysia (UUM).

As expected, role ambiguity is positively related to work-family conflict, but it's not significantly related to each other. As noticed the result after analysis shows that they are not significantly related and the hypothesis is not supported according to the research conducted in UUM. The reason is, role ambiguity is practice less in UUM, because the employee's responsibilities are divided equally and practice correctly without any doubt based on their work. In other words, a single person is not involved in bunch of works where there are divisions of work among the employees according to the work schedule. So that, the result shows that there is no support to the hypothesis and no significant relationship between the role ambiguity and work-family conflict.

The third hypothesis stated that the job demand is positively related to work-family conflict. Similarly, past studies such as (Boyar et al., 2008; Bakker et al., 2008; Lu et al, 2008; Biggart et al, 2009; Hall et al, 2010; Bakker et al., 2011; Beham et al., 2011; Shimozu et al., 2010) [21] [6] [56] [19] [39] [7] [10] [73], shows that the results of the present study stated a strong support for the third hypothesis. As determined, after the regression analysis, 
there exists a positive relationship among job demand and work-family conflict.

\subsection{Social Support as Moderator}

The fourth hypothesis was significantly and negatively supported by social support as it relates to the work-family conflict. This hypothesis was fully supported with the perception of social support significantly and negatively related to work-family conflict. This result is in line with prior researchers that found a negative relationship between the social support and work-family conflict (Thomas \& Ganster, 1995; Neilson et al., 2001; O’Driscoll et al., 2003; Daalen et al., 2006; Karatepe \& Kilie, 2007; Seiger \&Weise, 2009; Kossek et al, 2011) [79] [60] [64] [28] [46] [72] [49]. This shows that social support plays an important role to reduce the work-family conflict where the support from their supervisor, coworkers and family members give the employees the power to resolve their problem and reduce the work-family conflict.

Social support as a moderator which link between the job involvement and work-family conflict is the fifth hypothesis. Hypothesis 5 found that the moderator is significantly related to estimating, job involvement and work-family conflict. Besides, the social support was able to function as moderator between role ambiguity and workfamily conflict and there is a significant relationship between work-family conflict where it strengthens the relationship of role ambiguity and work-family conflict. The social support plays an important role where it creates less stress workplace with helpful members and understanding family members. The hypothesis 6 is supported and shows that the social support as a moderator has not tested before in the past research which links the role ambiguity and work-family conflict. Next is the hypothesis 7 which stated that the social support moderate between the job demand and work-family conflict shows positively and significantly supported. So that, have estimated social support can be used as a moderator between the job demand and work-family conflict and this shows that social support has strongly strengthened the relationship between job demand and work-family conflict. To the best of our knowledge, this is the first study where social support is tested as moderator in the midst of job involvement, job demand and work family conflict. Thus, this can be seen as a contribution from this study.

This study is an effort to explore the work-family conflict among the administrative staff in UUM, besides that to recognize the influences of the job involvement, role ambiguity and job demand on work-family conflict and investigates the effect of moderating between the independent variables and a dependent variable. The finding of this study is to provide a superior understanding for the outcome of the implication of job involvement, role ambiguity, job demand and social support on work-family conflict among the administrative staff in a public university (UUM). The employees need to dramatically reduce the level of work-family conflict, if not it will affect their work by creating less job satisfaction, lead to stress and most of the time the employees be disturbed mentally. Moreover, the employees can have a look on the "Wall Street Journal and Business Week" where these articles are weekly launched and dedicated towards the issues of workfamily (e.g., Brady, 2004; Shellenbarger, 2004) [22] [73]. Finally, the employees can also focus on books that are related to work-family conflict which said as the academic reader (e.g., Jacobs \& Gerson, 2005; Moen \&Roehling, 2005) [44] [57].

\section{Implications of the Study}

Commonly, most of the present studies that are conducted displayed their theoretical and practical implications. The theoretical and practical implication of this study is as shown below:

\subsection{Theoretical Implications}

The work-family conflict appears in an employee's life and this will be helpful to people in understanding the dynamisms of work-family conflict and its causes. There are some literatures which show consistent result based on work-family conflict and it's obliging to the work-family conflict contribution to the future research. Besides that, the independent variables (job involvement, role ambiguity and job demand) which have been used in the present study were found to give impact on work-family conflict. From this study, job involvement variable has seized to strengthen the organizational performance and work-family conflict, hence the past study describe the job involvement also affect the work-family conflict. Next is the job demand variable which has been used in the present study and shows there is a significant and positive relationship which strengthens the relationship between work-family conflict and supported by the prior study. At last, the social support as moderator among the independent variables (job involvement, role ambiguity and job demand) shows the significant relationship between work-family conflict in the present study.

\subsection{Practical Implications}

As affirmed at the beginning of this paper, the workfamily conflict might have a significant value towards the organizations. Based on the present study, the job involvement, role ambiguity and job demand are some of the interpreter to work-family conflict among the administrative staff of University Utara Malaysia (UUM). As verified by the past researches, high level of job involvement in an organization is allied with the low level of work-family conflict (Razak et al., 2011; Luk \& Shaffer, 2002; Lawrence, 2013; Narayanan \&Savarimuthu, 2013) [68] [55] [53] [59]. Similarly, the employees mostly related to higher job demand towards their work and this explains the reduction in work-family conflict (Hall et al., 2010; Shimozu et al., 2010; Bakker et al., 2011; Beham et al., 2011) [39] [74] [7] [10]. 
Apart from that, the social support increase shows that there is less work-family conflict among employees (Seiger \& Weise, 2009; Kossek et al., 2011; Karatepe \& Kilie, 2007; Daalen et al, 2006) [72] [49] [46] [28]. The social support as a moderator in job involvement, role ambiguity and job demand among the work-family conflict is stated as significant value, so that it's explained that the social support can be used as a moderator.

\section{Limitations and Future Direction}

There are several limitations that have been identified in this research which investigate work-family conflict on university administrative staff and management people. Firstly, the study has been conducted by cross-sectional design which represents the data collection made at one point of time. By adopting a longitudinal design in future research, where the data will be collected at the disparity of points in time will give the researchers' ability to draw a better conclusion. Moreover, the present study conducted with the target participants, which particularly focused on the administrative staff in public university that is positioned in Sintok, Malaysia. By this, it is found that not appropriate to generalize the results of the present study. It is suggested that future study need to be carried out to handle the collection of data from the various populations of such as private university administrative staff can be used as a sample for the future study to examine the result and make comparison with past researches. Furthermore, the present study was conducted with a small number of samples of respondents from the administrative staff in UUM. It is suggested that, for the future study a large sample of respondents needed to be employed to arrive at a better result or finding, so that the result can be acknowledged as accurate values. Future similar research should be conducted in any other public university in Malaysia to get more generalizes results than just in one public university in Malaysia.

\section{References}

[1] Abd Razak AZA, Yunus NKY, Nasurdin AM. The impacts of work overload and job involvement on work-family conflict among Malaysian doctors. Labuan Journal of Muamalat and Society 2011; 5: 1-10.

[2] Adams, G. A., King, L. A., \& King, D. W. (1996). Relationships of job and family involvement, family social support, and work-family conflict with job and life satisfaction. Journal of Applied Psychology, 81, 411420 .

[3] Ahmad, A. (2008). Job, family and individual factors as predictors of work-family conflict. The Journal of Human Resource and Adult Learning, 4(1), 57-67.

[4] Akanji, B. (2012). Realities of Work Life Balance in Nigeria: Perceptions of Role Conflict and Coping Beliefs. Business, Management and Education, 10(2), 248-263.
[5] Allen, T.D. (2001) Family supportive work environments: the role of organizational perceptions. Journal of Vocational Behavior. 58(3): 414-35.

[6] Bakker,A., B., Dollar., M.,F \& Demerauti., E. (2008).How Job Demands Affect Partners' Experience of Exhaustion: Integrating Work-Family Conflict and Crossover Theory. Journal of Applied Psychology. Copyright by the American Psychological Association, Vol. 93, No. 4, 901-911.

[7] Bakker.,A.,B., Brummelhuis., L.,L.,T., Prins., J.,T \& Heijden., D. (2011).Applying the job demands-resources model to the work-home interface: A study among medical residents and their partners.Journal of Vocational Behavior .79, 170-180.

[8] Baral, R., \& Bhargava, S. (2010). Work-family enrichment as a mediator between organizational interventions for work-life balance and job outcomes, Journal ofManagerial Psychology 25(3), 274-300.

[9] Baron, R.M. \& Kenny, D.A., (1986). The moderatormediator variable distinction in social psychological research: Conceptual, strategic, and statistical considerations J. Pers. Soc. Psychol. 51 (6), 1173-1182.

[10] Beham.,B., Drobnic., S., \& Prag., P. (2011.) Work demands and resources and the work-family interface: Testing a salience model on German service sector employees. Journal of Vocational Behavior 78, 110-122.

[11] Beigi,M., Ershadi., S.,M., \& Shirmohammadi .,M. (2012).Work-family conflict and its antecedents among Iranian operating room personnel. Management Research Review. Vol. 35 No. 10, 2012. Pp. 958-973.

[12] Beutell. J.N., (2013), Generational Differences in WorkFamily Conflict and Synergy. International Journal of Environmental Research and Public Health, 10(6):25442559.

[13] Bolat, T., Bolat, O. I., \& Yuksel, M. (2011). Relationship between Role Ambiguity and Burnout: The Mediating Effect of Organizational Culture. Interdisciplinary. Journal of Contemporary Research in Business, 2(10), 373-398.

[14] Boles, J. S., Howard, W. G., \& Donofrio, H. H. (2001). An investigation into the inter-relationships of work-family conflict, family-work conflict and worksatisfaction. Journal of Managerial Issues, 13(3), 376-390.

[15] Boyar,S.L. Maertz,C.P., Pearson, A.W., \& Keough. S. (2003). Work-family conflict: A model lingkages between work and family domain variables and turnover intentions. Journal of Managerial Issues, 15, 175-190.

[16] Burke, R. J., \& Greenglass, E. R. (2001). Hospital restructuring stressors, work and Family concerns and psychological well-being among nursing staff. Community,Work \& Family, 4(1), 49-62. doi: 10.1080/08870440108405528.

[17] Beham.,B., Drobnic., S., \& Prag., P. (2011.) Work demands and resources and the work-family interface: Testing a salience model on German service sector employees. Journal of Vocational Behavior, 78, 110-122.

[18] Beard, F. (1996). Marketing Client Role Ambiguity as a Source of Dissatisfaction in Client-Ad Agency Relationships. Journal of Advertising Research, 9-20. 
[19] Biggart., L., Corr, P., O’Brien., M., \& Cooper.N. (2009).Trait emotional intelligence and work-family conflict in fathers. L. Biggart et al. / Personality and Individual Differences 48, 911-916.

[20] Boyar,S.L., Carr,J.C., Mosley,D.C., Jr. \& Carson.C.M.(2007).The organizational Validation of Scores on Perceived Work and Family Demand Scales. Educational and Psychological Measurement. 67: 100: doi: 10.1177/0013164406288173.

[21] Boyar,S.,L., Maertz Jr., C.,P., Mosley Jr., D.,C., \& Carr.,J.,C .(2008).The impact of work/family demand on work-family conflict. Journal of Managerial Psychology. Vol. 23 No. 3, pp. 215-235.

[22] Brady,D.(2004). "Hoping aboard the Daddy Track", Business Week, 8 November, pp.100-101.

[23] Canivet,C., Ostergren, P.O., Lindeberg,S.S., Choi, B., Karasek, R.,Moghaddassi., \& M., Isacsson,S.O. (2010). Conflict between work and family domains and exhaustion among vocationally active men and women. Social Science and Medicine, 70, 1237-1245.

[24] Carlson, D. S., Kacmar, K. M., \& Williams, L. J. (2000) Construction and initial validation of a multidimensional measure of work-family conflict. Journal of Vocational Behavior, 56(2), 249-276.

[25] Carlson, D.S., \& Kacmar, K.M. (2000), "Work-family conflict in the organization: do life role values make a difference?" Journal of Management, Vol. 26 pp.1031-54.

[26] Chang, K.M. (2002). The Influences of Work-family Conflict and Sex-role Identity on Married Female Teacher's Job Involvement. Journal of Korean Home Economics Association English Edition: Vol. 3, No. 1.

[27] Chin,Y., F., Ismail., A., Ahmad, , R., H., \& Kuek., T.,Y. (2012). The Impacts of Job Stress Characteristics on the Workforce - Organizational Social Support as the Moderator. SAJMMR: South Asian Journal of Marketing \& Management Research.

[28] Daalen, G., V., Willemsen., T., M \& Sanders., K.(2006).Reducing work-family conflict through different sources of social support. Journal of Vocational Behavior.69. $462-476$.

[29] Doherty, A., \& Hoye, R. (2011). Role Ambiguity and Volunteer Board Member Performance in Nonprofit Sport Organizations. Nonprofit Management \& Leadership, 22(1), 107-128. http://dx.doi.org/10.1002/nml.20043.

[30] Dormann, C., \& Zapf, D. (1999). Social support, social stressors at work and depressive symptoms: Testing for main and moderating effects with structural equations in a three-wave longitudinal study. Journal of Applied Psychology, 84, 874-884.

[31] Epie, C. (2009). Managing time-based conflict across life domains in Nigeria: A decision making perspective. Ife Psychological, 17, 194-216.

[32] Erdwins, C. J., Buffardi, L. C., Casper, W. J., \& O’Brien, A. S. (2001). The Relationship of women's role strain to social support, role satisfaction, and self- efficacy. Journal of Family Relations, 50, 230-238.

[33] Falk, R. F., \& Miller, N. B. (1992). A primer for soft modeling. Ohio: The University of Akron Press.
[34] Fayankinnu, E. A., \& Alo, O. A. (2007). Globalization and work: An insight from the Ghanaian and Nigerian women experience, Gender and Behaviour, 5(1), 1129-1161.

[35] Frone, M. R., Russell, M., \& Cooper, M. L. (1992a). Antecedents and outcomes of work-family conflict: Testing a model of the work-family interface. Journal of AppliedPsychology, 77, 65-78.

[36] Frone, M. R., Russell, M., \& Cooper, M. L. (1992b). Prevalence of work-family conflict: Are work and family boundaries asymmetrically permeable? Journal of OrganizationalBehavior, 13,723-729.

[37] Greenhaus,G., \& Powell, G. (2006). When Work and Family are allies: A Theory of work-family enrichment. Academy of Management Review, 31, 72-92.

[38] Greenhaus, J.H., \& Beutell, N.J. (1985). Sources of Conflict between Work and Family Roles. Journal of the Academy of Management Review, Vol.10, No.1, pp.76-88.

[39] Hall, G.B., Dollard, M.F., Tuckey, M.R., Winefield, A.H. \& Thompson, B.M. (2010). Job demands, work-family conflict and emotional exhaustion in a longitudinal study: Reciprocal mediated relations among Australian frontline police. Journal of Occupational and Organizational Psychology, 83, 237-250.

[40] Hammer, L. B., Kossek, E. E., Yragui, N. L., Bodner, T. E., \& Hanson, G. C. (2009). Development and validation of a multidimensional measure of family supportive supervisor behaviors (FSSB). Journal of Management, 35: 837-856.

[41] Hellman. C. (1997). Job Satisfaction and Intent to leave. Journal of Social Psychology, No.137, 677-689.

[42] House, Robert J. and John R. Rizzo (1972), "Role Conflict and Ambiguity as Critical Variables in a Model of Organizational Behavior," Organizational Behavior andHuman Performance, Vol. 7, June, pp. 467-505. http://factfinder.census.gov, (accessed August 2005).

[43] Jackson, M.A., Tal. A.I. \& A.R.Sullivan. (2003). Hidden Biases in Counseling Women, Kopala, M. and M.A. Keitel (Eds.). Thousand Oaks, C.A., Sage.

[44] Jacobs, J. \& Garson, K. (2005).The Time Divide: Work, Family and GenderInequality, Harvard University Press, Cambridge, MA.

[45] Kanungo,R .N. (1982). Work alienation: An integrative approach. New York: Praeger.

[46] Karatepe, O.M., \& Kilie, H. (2007), "Relationship of Supervisor Support and Conflicts in the work family interface with the selected job outcomes of frontline employees". Tourism Management, Vol.28 No.1, pp.238252.

[47] Karatepe,Osman.,M. (2013) "The effects of work overload and work-family conflict on job embeddedness and job performance: The mediation of emotional exhaustion", International Journal of Contemporary Hospitality Management, Vol. 25 Iss: 4, pp.614 - 634 .

[48] Kahn, Wolfe, Quinn, Snoek, \& Rosenthal. (1964). Linkage between Worksite Support with Work Role Expectation, Role Ambiguity and Its Effects on Work- Family Conflict. Canadian Academy of Oriental and Occidental Culture. 
[49] Kossek, E.E., Pichler, S., Bodner, T., \& Hammer, L., B. (2011). Workplace Social Support and Work-Family Conflict: A Meta- Analysis Clarifying the Influence of General and Work-Family Specific Supervisor and Organizational Support. In Press at Personnel Psychology.

[50] Koys, D.J. (2001). The Effect of employees Satisfaction, Organisational Citizenship Behavior and Turnover on Organizational Effectiveness: A Unit-Level, Longitudinal Study. Personal Psychology, Vol.54 (1).

[51] Krejcie, R. V., \& Morgan, D.W. (1970). Determining sample size for research activities. Educational and Psychological Measurement 30, 607-610.

[52] Lakey, B., \& Cohen, S. (2000). Social support theory and measurement. In S. Cohen, L. Underwood, \& B. H. Gottlieb (Eds.), Social support measurement and intervention: $A$ guide for health and social scientists (pp. 29-52). New York: Oxford University Press.

[53] Lawrence. A. (2013), Impact of work-family involvement on work-family conflict of non professional Igbo Nigeria employees. African Journal of Business Management.

[54] Lodahl, T.M., \& Kejner, M. (1965). Definition and measurement of job involvementJournal of Applied Psychology, Vol 49, pp.24-33.

[55] Luk.D.M., and Shaffer. M.A. (2002). Work and Family Domain Stressors, Structure and Support: Direct and Indirect Influences on Work-Family Conflict. School of Business, Business Research Center. Published in Bangkok.

[56] Lu, L., Kao, S.F., Chang, T, Wu, H. \& Cooper. C.L. (2008). Work/Family Demands, Work Flexibility, Work/ Family Conflict, and Their Consequences at Work: A National Probability Sample in Taiwan. International Journal of Stress Management, Copyright by the American Psychological Association, Vol. 15, No. 1, 1-21.

[57] Moen,P.,\& Roehling,P.(2005), The Career Mystique: Cracks in the American Dream, Rowman \& Littlefield Publishes, Inc., New York.

[58] Mauno, S., Kinnunen, U., \& Ruokolainen, M. (2006). Exploring work- and organization based resources as moderators between work and family conflict, well-being, and job attitudes. Work \& Stress, 20(3), 210233.doi:10.1080/02678370600999969

[59] Narayanan, S. L., \& Savarimuthu, A. (2013). Work-Family conflict-An exploratory study of the dependents child's age on working mothers. Review of Integrative Business and Economics Research. Vol2 (1).

[60] Neilson,T.,R., Calson.,D.,S \& Lankau.,M.,J.(2001).The Supportive Mentor as a Means of Reducing Work-Family Conflict. Journal of Vocational Behavior,59, 364-381, doi:10.1006/jvbe.2001.1806, available online at $\mathrm{http}: / /$ www.idealibrary.com on IDEAL.

[61] Netermeyer, R. G., Boles, J. S., \& McMurrian, R. (1996). Development and validation of work-family conflict and family-work conflict scales. Journal of Applied Psychology, 81(4), 400-410

[62] Ng, T.W.H., \& Sorensen, K.L. (2008), "Toward a further understanding of the relationships between perceptions of support and work attitudes: a meta-analysis", Group and Organization Management, Vol. 33 No.3, pp.243-268.
[63] O’Driscoll, M. P., Brough, P., \& Kalliath, T. J. (2004). Work/family conflict, psychological well-being, satisfaction and social support: A longitudinal study in New Zealand. Equal Opportunities International, 23(1/2), 36-56.

[64] O’Driscoll,M.P., Poelmans,S., Spector,P.,E., Kalliath,T., Allen, Tammy,D., Cooper.,C.,L \& Sachez.,J.,I. (2003). Family-Responsive Interventions, PerceivedOrganizational and Supervisor Support, Work-Family Conflict, and Psychological Strain. International Journal of Stress Management, Vol. 10, No. 4, 326-344.

[65] Parasuraman, S., \& Greenhaus, J. H. (1992). An exchange perspective on support provided by partners in two-career relationships. Paper presented at the annual meeting of the Academy of Management, Atlanta, GA.

[66] Poobalan. (2013), Marriage and Divorce Statistics in Malaysia 2008-2012. Retrieved 20 April 2014 from $\mathrm{http} / /$ poobalan.com/blog/others/2013/12/11/marriage-anddivorce-statistics-in-malaysia-2008-2012.

[67] Rahim, M. H. A., Zukni, R. Z. J. A., Ahmad, F., \& Lyndon, N. (2012). Green Advertising and Environmentally Responsible Consumer Behavior: The Level ofAwareness and Perception of Malaysian Youth. Asian Social Science, $8(5), 46-54$.

[68] Razak AZA, Yunus NKY, Nasurdin M (2011). Impact of work overload and job involvement on work-family conflict among Malaysian doctors. Labuan e-Journal Maumalat Soc. $5: 1-10$.

[69] Rizzo, J. R., House, R. J., \& Lirtzman, S. I. (1970). Role conflict and ambiguity in complex organizations. Administrative science quarterly, 150-163.pp.151.

[70] Robinson, J.P., Shaver, P.R., \& Wrightsman, L.S. (1991). Criteria for scale selection and evaluation. In J.P. Robinson, P.R. Shaver \& L.S.Wrightsman (Eds.), Measures of Personality and Social Psychological Attitudes (pp.1-15). San Diego: Academic Press.

[71] Sakires, J., Dohert, A., \& Misener, K. (2009). Role Ambiguity in Voluntary Sport Organizations. Journal of Sport Management, 23, 615-643.

[72] Seiger, C., P., Wiese. B., S. (2009). Social Support from work and family domains as an antecedent or moderator of workfamily conflicts? Journal of Vocational Behavior. 26-37.

[73] Shellenbarger, S. (2004, June3). "The Juggling Act Revisited," Wall Street Journal. NY: D.1.

[74] Shimozu, A., Bakker, A., B., Demerouti., E., \& Peeters., M.,C.,W. (2010). Work- family Conflict in Japan: How Job and Home Demands Affect Psychological Distress. Industrial Health, 48, 766-774.

[75] Simon, M., Kummerling, A., \& Hasselhorn, H. M. (2004). Work-Home Conflict in the European Nurisng Profession. International Journal of Occupational and Environemental Health, 10(4), 384-391.

[76] Spector, P. E. (1997). Job satisfaction: application, assessment, cause, and consequences. Thousand Oaks, CA: Sage Publications.

[77] Tabachnick, B.G., \& Fidell, L.S. (2007). Using multivariate statistics (5thEd.). Boston, MA:Allyn \& Bacon/Pearson Education. 
[78] Thiagarajan, P, Chakrabarty, S., Lueg, J. E., \& Taylor, R. D. (2007). Work-Family Role Strain of Single Parents: The Effects of Role Conflict and Role Ambiguity. The Marketing Management Journal, 17(1), 82-94.

[79] Thomas, L. T. \& Ganster, D.C. (1995). Impact of FamilySupportive Work Variables on Work-Family Conflict and Strain: A Control Perspective. Journal of AppliedPsychology, 80, 6-15 doi:10.1037/0021-9010.80.1.6.

[80] Westman, M., \& Etzion, D.L. (2005). The crossover of work-family conflict from one spouse to the other. Journal of Applied Social Psychology, 35, 1936-1957.
[81] Yildirim, D., \& Aycan, Z. (2007). Nurses' work demands and work-family conflict: A questionnaire survey. International Journal of Nursing Studies.

[82] Zhang. M, Griffeth. R. W \& Fried. D.D, (2012). "WorkFamily Conflict and Individual Consequences", Journal of Managerial Psychology, 27, No.7. 